\title{
Tolerance of Soybean (Glycine max L.) to Protoporphyrinogen Oxidase Inhibitors and Very Long Chain Fatty Acid Synthesis Inhibitors Applied Preemergence
}

\author{
Kris J. Mahoney ${ }^{1}$, François J. Tardif ${ }^{2}$, Darren E. Robinson ${ }^{1}$, Robert E. Nurse ${ }^{3}$, \\ Peter H. Sikkema ${ }^{1}$ \\ ${ }^{1}$ University of Guelph, Ridgetown Campus, Ridgetown, Canada \\ ${ }^{2}$ University of Guelph, Guelph, Canada \\ ${ }^{3}$ Agriculture and Agri-Food Canada, Harrow, Canada \\ Email: ${ }^{*}$ kmahoney@uoguelph.ca
}

Received 21 December 2013; revised 19 February 2014; accepted 15 March 2014

Copyright (C) 2014 by authors and Scientific Research Publishing Inc.

This work is licensed under the Creative Commons Attribution International License (CC BY). http://creativecommons.org/licenses/by/4.0/

(c) (i) Open Access

\begin{abstract}
Nine field experiments were conducted in 2011 and 2012 at various locations in southern Ontario, Canada to determine the tolerance of soybean (Glycine max (L.) Merr.) to herbicides inhibiting protoporphyrinogen oxidase (Protox) and very long chain fatty acid (VLCFA) synthesis applied alone and in combination. Preemergence applications were evaluated for soybean injury, plant height, shoot dry weight, and yield in the absence of weed competition. Early-season soybean injury from the Protox inhibitors persisted 4 weeks after soybean emergence (WAE) with $3 \%, 5 \%$, and $18 \%$ injury for flumioxazin, saflufenacil, and sulfentrazone, respectively. When Protox inhibitors were tank mixed with VLCFA inhibitors (i.e., dimethenamid-P, $S$-metolachlor, and pyroxasulfone), additive interactions were observed for injury with saflufenacil and sulfentrazone; whereas synergistic interactions were observed with flumioxazin. However, injury subsided over time decreasing from as much as $34 \%$ injury 1 WAE for the flumioxazin $+S$-metolachlor tank mix down to $9 \%$ injury 4 WAE. In general, when saflufenacil or flumioxazin were tank mixed with VLCFA inhibitors, greater than expected reductions in height and dry weight were observed indicating synergistic responses; while no interactive effects were detected with sulfentrazone and VLCFA inhibitor tank mixes. For the flumioxazin tank mixes that contained dimethenamid-P or $S$-metolachlor, the reduction in yield was greater than expected indicating synergistic interactive effects. Yet, all the demonstrated impacts were transient as the yield for soybean treated with any of the Protox inhibitor and VLCFA inhibitor tank mixes tested were similar to the untreated con-
\end{abstract}

\footnotetext{
*Corresponding author.
} 
trol. Therefore, usage restriction on these mixtures, based on perceived negative yield impact, should be lifted so the herbicides could be combined to expand weed control options.

\title{
Keywords
}

\author{
Flumioxazin; Sulfentrazone; Saflufenacil; Pyroxasulfone; Dimethenamid-P; $S$-Metolachlor; \\ Synergism; Antagonism
}

\section{Introduction}

Herbicide premixes and tank mixes are commonly used in weed management to increase the spectrum of weeds controlled and, in glyphosate-resistant crops, increase the diversity of modes of action used in production systems often dominated by a single herbicide [1]-[3]. Yet, when applied in combination, herbicides can perform unpredictably, having antagonistic, additive, or synergistic interactions compared to applications of a single herbicide [4]. Additive responses of herbicide combinations occur when the observed and expected responses are similar, whereas antagonistic and synergistic responses are characterized by the observed response being less than and greater than expected, respectively [5]. The herbicide label for flumioxazin, primarily a broadleaf weed herbicide that inhibits the protoporphyrinogen oxidase (Protox) enzyme [6] [7], warns users about the potential for greater than expected soybean (Glycine max (L.) Merr.) injury if tank mixed with chloroacetamide herbicides (e.g., dimethenamid-P and $S$-metolachlor) for additional grass weed control [8]. Interestingly, other Protox inhibitors that share a similar preemergence (PRE) use pattern (e.g., saflufenacil and sulfentrazone) do not have a similar tank mix restriction on the label [9] [10] and can be found in proprietary premixes with dimethenamid-P [11] and $S$-metolachlor [12].

The chloroacetamides, a relatively old class of herbicides [13], inhibit the growth of susceptible seedling roots and shoots by targeting enzymes required for the biosynthesis of very long chain fatty acids (VLCFA) [7] [13]. Pyroxasulfone is a relatively new herbicide with a mode of action similar to "classic" chloroacetamides; yet, pyroxasulfone has been shown to target fundamentally different sites of activity in a plant's endoplasmic reticulum [14]. Recently, pyroxasulfone has been premixed with flumioxazin and registered as Fierce ${ }^{\circledR}$ (Valent USA Corporation, Walnut Creek, CA), a PRE herbicide for use in soybean and other crops [15]. Significant earlyseason soybean injury has been reported when using this flumioxazin/pyroxasulfone premix; however, the injury was transient and did not affect yield [16]-[20].

Soybean responses to Protox inhibitors alone [21]-[25] and in combination with VLCFA inhibitors [16] [26][28] have been reported in the literature. However, an examination of interactive effects was usually not the main objective of the research. Furthermore, there are limited published data on side-by-side comparisons of Protox inhibitor and VLCFA inhibitor tank mixes in soybean [29] with a focus on the potential interactive effects. Reference [30] emphasized the importance of understanding of how herbicides perform in mixtures so that herbicide labels can be developed and new herbicides can be positioned for use in the marketplace. Therefore, the objectives of this study were to 1) determine if the injury warning on the flumioxazin label is warranted, and 2) compare PRE treatments of Protox inhibitors and VLCFA inhibitors alone and in tank mixes on crop injury and soybean yield.

\section{Materials and Methods}

A total of nine field experiments were conducted over a two-year period (2011 and 2012) at various locations in southern Ontario, Canada (Table 1). The experiment was arranged as a $16 \times 4$ two-way factorial, randomized complete block design replicated four times. Herbicide was factor one and soybean cultivar was factor two. Glyphosate-resistant soybean cultivars (PROSeeds/Sevita PRO 2715R, PRIDE seeds 5201RR2Y, DEKALB 28-60RY, and Country Farms Seeds 5221 RR2Y) were seeded $4 \mathrm{~cm}$ deep in rows spaced $75 \mathrm{~cm}$ apart into plots 3 $\mathrm{m}$ wide by 8 or $10 \mathrm{~m}$ long using a conventional planter. Herbicide treatments were applied PRE using a $\mathrm{CO}_{2}$ pressurized backpack sprayer calibrated to deliver $200 \mathrm{~L} \cdot \mathrm{ha}^{-1}$ of water at $207 \mathrm{kPa}$ through four Hypro Ultra-low drift 120-02 nozzles (Hypro, New Brighton, MN) spaced $50 \mathrm{~cm}$ apart. The Protox inhibitors (sulfentrazone, flumioxazin, and saflufenacil applied at 840,142 , and $50 \mathrm{~g} \cdot \mathrm{ai} \cdot \mathrm{ha}^{-1}$, respectively) and VLCFA inhibitors (dimethenamid-P, S-metolachlor, and pyroxasulfone applied at 1386, 3200, and $376 \mathrm{~g} \cdot$ ai $^{\circ} \mathrm{ha}^{-1}$, respectively) were applied 
Table 1. Environment; soil characteristics; soybean seeding rate and date; spray date; and harvest for studies evaluating the interactions of preemergence protoporphyrinogen oxidase (Protox) inhibiting and very long chain fatty acid (VLCFA) synthesis inhibiting herbicides in Ontario, Canada in 2011 and 2012.

\begin{tabular}{|c|c|c|c|c|c|c|c|c|}
\hline \multicolumn{2}{|c|}{ Environment } & \multicolumn{3}{|c|}{ Soil characteristics } & \multicolumn{2}{|c|}{ Soybean seeding } & \multirow[t]{3}{*}{ Spray date } & \multirow[t]{3}{*}{ Harvest date } \\
\hline \multirow{2}{*}{ Location $^{a}$} & \multirow{2}{*}{ Year } & \multirow{2}{*}{ Texture } & \multirow{2}{*}{$\begin{array}{c}\text { Organic matter } \\
\%\end{array}$} & \multirow{2}{*}{$\mathbf{p H}$} & Rate & \multirow{2}{*}{ Date } & & \\
\hline & & & & & seeds $\cdot \mathrm{ha}^{-2}$ & & & \\
\hline Exeter & 2011 & clay loam & 3.4 & 7.7 & 360,000 & 6-June & 9-June & 11-Oct \\
\hline Harrow & 2011 & sandy loam & 2.0 & 6.1 & 380,000 & 14-June & 16-June & $10-$ Oct \\
\hline Ridgetown & 2011 & sandy loam & 5.6 & 6.4 & 370,000 & 2-June & 3-June & 11-Oct \\
\hline Woodstock & 2011 & silt loam & 4.8 & 7.7 & 390,000 & 9-June & 13-June & 27-Oct \\
\hline Elora & 2012 & silt & 4.2 & 7.4 & 390,000 & 24-May & 26-May & 22-Oct \\
\hline Exeter & 2012 & loam & 3.8 & 7.8 & 360,000 & 14-May & 14-May & 25-Sept \\
\hline Harrow & 2012 & sandy loam & 2.0 & 6.1 & 380,000 & 7-June & 8-June & 25-Oct \\
\hline Ridgetown & 2012 & loam & 6.5 & 6.7 & 370,000 & 23-May & 23-May & 4-Oct \\
\hline Woodstock & 2012 & silt loam & 4.8 & 7.7 & 390,000 & 17-May & 17-May & 11-Oct \\
\hline
\end{tabular}

${ }^{\mathrm{a}}$ Elora $\left(43^{\circ} 40^{\prime} \mathrm{N} 80^{\circ} 25^{\prime} \mathrm{W}\right)$, Exeter $\left(43^{\circ} 20^{\prime} \mathrm{N} 81^{\circ} 28^{\prime} \mathrm{W}\right)$, Harrow $\left(42^{\circ} 2^{\prime} \mathrm{N} 82^{\circ} 55^{\prime} \mathrm{W}\right)$, Ridgetown $\left(42^{\circ} 26^{\prime} \mathrm{N} 81^{\circ} 53^{\prime} \mathrm{W}\right)$, and Woodstock $\left(43^{\circ} 7{ }^{\prime} \mathrm{N} 80^{\circ} 44^{\prime} \mathrm{W}\right)$.

alone or in combination. The rates selected are twice the manufacturers' labeled rate in Ontario to represent a spray overlap in the field. Untreated controls, in addition to the PRE herbicide treatments, were included in each replicate of each trial; all treatments were maintained weed-free for the entire growing season using glyphosate and hand weeding as needed.

Visible soybean injury was rated 1, 2, and 4 weeks after soybean emergence (WAE) based on a scale of 0 (no injury) to $100 \%$ (complete plant death). Average plant height was recorded at the $2^{\text {nd }}$ and $4^{\text {th }}$ trifoliate leaf stage (approximately 2 and 4 WAE, respectively) by measuring the height of plants from the soil surface to the growing point of the plant. Shoot dry weight 2 WAE was determined by harvesting plants at the soil surface, placing them in a paper bag, drying them to constant moisture, and recording the dry weight. At maturity, plants were harvested with a small plot combine, weight and moisture were recorded, and yields were adjusted to 13\% moisture content.

\section{Statistical Analysis}

Data for soybean injury, plant height, shoot dry weight, and yield were analyzed using PROC MIXED (SAS Ver. 9.2, SAS Institute Inc., Cary, NC). Variances were divided into fixed (herbicide treatment, soybean cultivar, and the herbicide treatment $\times$ soybean cultivar interaction) and random effects [block; environment (i.e., location-year combinations); and the interactions of herbicide treatment $\times$ environment, soybean cultivar $\times$ environment, and herbicide treatment $\times$ soybean cultivar $\times$ environment]. The significance of fixed effects was tested using an F-test and the significance of random effects was tested using a Z-test of the variance estimate. Factor two (soybean cultivar) and the herbicide treatment $\times$ soybean cultivar interaction were not significant $(P=0.1543$ and $P=$ 0.9623, respectively); therefore, data were pooled across cultivars. Furthermore, the herbicide treatment $\times$ environment interaction was not significant and the data were pooled by environment. PROC UNIVARIATE in SAS was used to test data for normality and homogeneity of variance. To satisfy the assumptions of ANOVA, crop injury and shoot dry weight data were transformed using arcsine square root and log transformations, respectively. Plant height and yield data met the assumptions of normality and no transformations were necessary. Data compared on the transformed scale were converted back to the original scale for presentation of results.

Colby's equation [5] was used to determine the expected soybean injury from herbicide combination means by using the observed means for a Protox inhibitor $(A)$ alone and a VLCFA inhibitor $(B)$ alone.

$$
\text { Expected }=(A+B)-[(A \times B) / 100]
$$

Plant height, shoot dry weight, and yield were calculated as a percent of the untreated control and Colby's 
modified equation [5] for percent of control values was used to determine the expected herbicide combination means.

$$
\text { Expected }=(A \times B) / 100
$$

Following the calculation of the expected means, observed and expected means were compared using a paired $t$-test at the $P<0.05$ level of significance in order to determine additive, synergistic, or antagonistic effects.

Soybean injury, height, shoot dry weight, and yield data were compared using pre-planned orthogonal contrasts in PROC MIXED in SAS. The contrasts that were evaluated included: 1) untreated vs VLCFA inhibitors, 2) untreated vs Protox inhibitors, 3) sulfentrazone vs sulfentrazone + a VLCFA inhibitor, 4) flumioxazin vs flumioxazin + a VLCFA inhibitor, and 5) saflufenacil vs saflufenacil + a VLCFA inhibitor.

\section{Results and Discussion}

\subsection{Injury}

Both herbicide groups caused greater soybean injury than the untreated control 1 and 2 WAE (Table 2, Contrasts 1 and 2). By 4 WAE, no difference in injury was detected between treated and untreated soybeans for the VLCFA inhibitors $(P=0.49)$. Conversely, for the Protox inhibitors, soybean injury persisted 4 WAE with $3 \%, 5 \%$, and $18 \%$ injury for flumioxazin, saflufenacil, and sulfentrazone, respectively (Table 2). Similar levels of soybean injury have been reported for saflufenacil [21] [24]; while flumioxazin and sulfentrazone injury in soybean has been shown to vary between years [22] [23] and substantially among cultivars [25].

Tank mixes of Protox inhibitors and VLCFA inhibitors caused greater injury than Protox inhibitors applied alone 1, 2, and 4 WAE (Table 2, Contrasts 3 to 5). For sulfentrazone and saflufenacil, paired $t$-tests indicated that tank mixes with VLCFA inhibitors resulted in additive interactions. Whereas with flumioxazin, the responses were generally synergistic as greater than expected injury was observed. However, injury subsided over time; for example, decreasing from as much as $34 \%$ injury $1 \mathrm{WAE}$ for the flumioxazin $+S$-metolachlor tank mix down to $9 \%$ injury 4 WAE (Table 2). References [28] and [27] reported similar levels of soybean injury approximately 4 WAE. However, compared to this study, substantially lower rates of the tank mix herbicides were used. For instance, 7\% injury was observed using $71 \mathrm{~g} \cdot \mathrm{ai}^{\mathrm{h}} \mathrm{ha}^{-1}$ of flumioxazin $+1100 \mathrm{~g} \cdot \mathrm{ai} \cdot \mathrm{ha}^{-1}$ of $S$-metolachlor [28] and $12 \%$ injury was observed using $96 \mathrm{~g} \cdot \mathrm{ai} \cdot \mathrm{ha}{ }^{-1}$ of flumioxazin $+1070 \mathrm{~g} \cdot \mathrm{ai}^{-\mathrm{ha}^{-1}}$ of $S$-metolachlor [27]. In this study, for the tank mix treatment that approximates the Fierce ${ }^{\circledR}$ premix [15], $10 \%$ injury was observed with $142 \mathrm{~g} \cdot \mathrm{a} \cdot \mathrm{h}^{-1} \mathrm{of}^{-1}$ flumioxazin + $376 \mathrm{~g} \cdot \mathrm{ai}^{-h^{-1}}{ }^{-1}$ of pyroxasulfone 4 WAE (Table 2). Reference [16] found that $105 \mathrm{~g} \cdot \mathrm{a} \cdot \mathrm{ha}^{-1}$ of flumioxazin +134

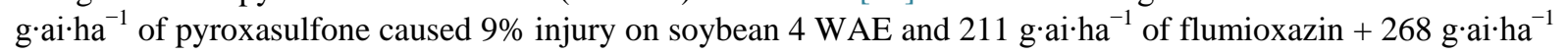
of pyroxasulfone caused $19 \%$ injury.

\subsection{Height}

Plant height was not decreased by Protox inhibitors or VLCFA inhibitors applied alone (Table 2, Contrasts 1 and 2); however, soybean height was reduced in some tank mix treatments (Table 2, Contrasts 3 to 5). Soybean has been shown to tolerate up to $100 \mathrm{~g} \cdot \mathrm{ai} \cdot \mathrm{ha}^{-1}$ of saflufenacil [24] and $210 \mathrm{~g} \cdot \mathrm{ai} \cdot \mathrm{ha}^{-1}$ of flumioxazin [25] without a reduction in plant height. For sulfentrazone applied at 350 or $448 \mathrm{~g} \cdot \mathrm{ai}^{\mathrm{h}} \mathrm{ha}^{-1}$, soybean height was reduced by $11 \%$ [31] or more [25], similar to this study. Yet, when sulfentrazone was tank mixed with VLCFA inhibitors, interactions were not detected (Table 2, Contrast 3). However for saflufenacil and flumioxazin, synergistic responses were observed as greater than expected reductions in crop height occurred when these Protox inhibitors were tank mixed with VLCFA inhibitors (Table 2, Contrasts 4 and 5). The lone exception was the saflufenacil + dimethenamid-P tank mix; paired $t$-tests indicated that the responses were additive. But by the $4^{\text {th }}$ trifoliate stage, soybean height was no different than the untreated control (Table 2). These were interesting, but not unexpected observations since this treatment approximates a commercially available premix [12].

\subsection{Dry Weight}

Similar to crop height, there was no difference between the VLCFA inhibitor treated and the untreated soybeans (Table 2, Contrast 1); but relative to the untreated control, significant reductions in dry weight $(P=0.03)$ were detected in the Protox inhibitor treatments (Table 2, Contrast 2). These differences were likely driven by sulfentrazone as soybean plants treated with $840 \mathrm{~g} \cdot \mathrm{ai} \cdot \mathrm{ha}^{-1}$ had a $20 \%$ reduction in dry weight compared to the untreated 
Table 2. Percent soybean visible injury and percent height, dry weight, and yield in comparison to an untreated control when treated with preemergence protoporphyrinogen oxidase (Protox) inhibiting and very long chain fatty acid (VLCFA) synthesis inhibiting herbicides alone or in combination at nine locations in Ontario, Canada in 2011 and 2012 ${ }^{\mathrm{a}}$.

\begin{tabular}{|c|c|c|c|c|c|c|c|}
\hline \multirow{2}{*}{ Treatment } & \multicolumn{3}{|c|}{ Injury $(\%)^{b}$} & \multicolumn{2}{|c|}{ Height $(\%)^{c}$} & \multirow{2}{*}{$\begin{array}{l}\text { Dry Weight } \\
(\%)^{\mathrm{c}}\end{array}$} & \multirow{2}{*}{ Yield (\%) } \\
\hline & 1 WAE & 2 WAE & 4 WAE & $2^{\text {nd }}$ trifoliate & $4^{\text {th }}$ trifoliate & & \\
\hline Untreated control & 0 & 0 & 0 & 100 & 100 & 100 & 100 \\
\hline Dimethenamid-P & 5 & 5 & 1 & 97 & 101 & 95 & 103 \\
\hline$S$-metolachlor & 13 & 9 & 1 & 99 & 101 & 96 & 103 \\
\hline Pyroxasulfone & 6 & 4 & 1 & 99 & 100 & 102 & 100 \\
\hline Sulfentrazone & 8 & 12 & 18 & 93 & 89 & 80 & 100 \\
\hline Sulfentrazone + dimethenamid-P & $14(13)$ & $15(17)$ & $17(18)$ & $90(91)$ & $88(90)$ & $77(80)$ & $96(97)$ \\
\hline Sulfentrazone $+S$-metolachlor & $20(20)$ & $18(20)$ & $14(18)$ & $91(93)$ & $90(90)$ & $80(83)$ & 99 (99) \\
\hline Sulfentrazone + pyroxasulfone & $13(13)$ & $13(16)$ & $14(19)$ & $89(93)$ & $89(89)$ & $80(88)$ & 97 (95) \\
\hline Flumioxazin & 12 & 8 & 3 & 101 & 104 & 99 & 110 \\
\hline Flumioxazin + dimethenamid-P & $27(16)$ & $16(13)$ & $9(4)$ & $88(99)$ & $96(105)$ & $81(96)$ & $105(114)$ \\
\hline Flumioxazin $+S$-metolachlor & $34(23)$ & $19(16)$ & $9(4)$ & $86(101)$ & 95 (106) & 77 (101) & $103(112)$ \\
\hline Flumioxazin + pyroxasulfone & $24(16)$ & $16(12)$ & $10(5)$ & 89 (101) & 95 (105) & $83(108)$ & $102(107)$ \\
\hline Saflufenacil & 4 & 7 & 5 & 101 & 99 & 100 & 103 \\
\hline Saflufenacil + dimethenamid-P & $11(9)$ & $12(11)$ & $8(6)$ & $94(98)$ & $96(100)$ & $92(96)$ & 97 (101) \\
\hline Saflufenacil + S-metolachlor & $17(16)$ & $14(15)$ & $9(6)$ & $93(101)$ & $93(100)$ & 89 (99) & 99 (102) \\
\hline Saflufenacil + pyroxasulfone & $7(9)$ & $10(11)$ & $10(7)$ & $90(101)$ & $92(99)$ & $86(104)$ & $95(97)$ \\
\hline $\mathbf{L S D}_{0.05}$ & 3.9 & 3.3 & 3.6 & 5.8 & 4.2 & 8.4 & 6.6 \\
\hline \multicolumn{8}{|l|}{ Contrasts (P-values) $^{d}$} \\
\hline 1) Untreated vs VLCFA inhibitors & 0.0001 & 0.0001 & 0.49 & 0.39 & 0.72 & 0.38 & 0.51 \\
\hline 2) Untreated vs Protox inhibitors & 0.0001 & 0.0001 & 0.0001 & 0.42 & 0.08 & 0.03 & 0.09 \\
\hline $\begin{array}{l}\text { 3) Sulfentrazone vs sulfentrazone } \\
\text { + a VLCFA inhibitor }\end{array}$ & 0.0001 & 0.008 & 0.04 & 0.29 & 0.79 & 0.70 & 0.28 \\
\hline $\begin{array}{l}\text { 4) Flumioxazin vs flumioxazin } \\
\text { + a VLCFA inhibitor }\end{array}$ & 0.0001 & 0.0001 & 0.0001 & 0.0001 & 0.0001 & 0.0001 & 0.01 \\
\hline $\begin{array}{l}\text { 5) Saflufenacil vs saflufenacil } \\
\text { + a VLCFA inhibitor }\end{array}$ & 0.0001 & 0.0001 & 0.03 & 0.0004 & 0.004 & 0.009 & 0.03 \\
\hline
\end{tabular}

${ }^{a}$ Abbreviation: WAE, weeks after soybean emergence. ${ }^{b}$ Expected responses, based on Colby's equation $(E=(A+B)-[(A \times B) / 100])$, for tank mixes are shown in parentheses following each observed response. Significant differences based on a paired $t$-test between observed and expected values are indicated in bold. 'Expected responses, based on Colby's modified equation $(E=[A \times B] / 100)$, for tank mixes are shown in parentheses following each observed response. Significant differences based on a paired $t$-test between observed and expected values are indicated in bold. ${ }^{\mathrm{d}}$ For convenience, significant $P$-values are indicated in bold.

control (Table 2). For susceptible cultivars, up to a 56\% reduction in soybean dry weight has been documented using $560 \mathrm{~g} \cdot \mathrm{ai} \cdot \mathrm{ha}^{-1}$ of sulfentrazone [32].

Tank mixes of VLCFA inhibitors with sulfentrazone caused no interactions (Table 2, Contrast 3), but interactive effects were detected for saflufenacil and flumioxazin (Contrasts 4 and 5). Greater than expected reductions in dry weight (from $14 \%$ to $23 \%$ ) occurred in tank mixes that contained either flumioxazin or pyroxasulfone, indicating synergistic responses (Table 2). For saflufenacil tank mixes containing dimethenamid-P or $S$-metolachlor, paired $t$-tests indicated that the interactive effects were additive. Yet, just as in the crop height data, soybean dry 
weight for the saflufenacil + dimethenamid-P tank mix was similar to the untreated control (Table 2), indicative of a herbicide combination with minimal injury potential [26].

\subsection{Yield}

For Protox inhibitors and VLCFA inhibitors applied alone, there were no differences in yield between the treated and untreated soybeans (Table 2, Contrasts 1 and 2). Similar to dry weight, interactive effects were not detected ( $P$ $=0.28$ ) when VLCFA inhibitors were tank mixed with sulfentrazone (Table 2, Contrast 3). Reference [31] similarly found no soybean yield differences between treatments containing $350 \mathrm{~g} \cdot \mathrm{ai} \cdot \mathrm{ha}^{-1}$ of sulfentrazone and a tank mix that contained $350 \mathrm{~g} \cdot \mathrm{ai} \cdot \mathrm{ha}^{-1}$ of sulfentrazone $+1120 \mathrm{~g} \cdot \mathrm{ai} \cdot \mathrm{ha}^{-1}$ of $S$-metolachlor. Contrary to this study where soybean yield was not confounded by weed competition, soybean yield in their study was contingent on weed control as applications of glyphosate outperformed both of the aforementioned sulfentrazone treatments [31].

Much like crop height and dry weight, soybean yield was influenced by interactions between both saflufenacil or flumioxazin and the VLCFA inhibitors (Table 2, Contrasts 4 and 5). For tank mixes that contained saflufenacil and/or pyroxasulfone, paired $t$-tests indicated that the interaction was additive. Whereas for the flumioxazin tank mixes that contained dimethenamid-P or $S$-metolachlor, the reduction in yield was greater than expected, indicating synergistic interactive effects (Table 2). Yet despite the appearance of the interactive effects, whether additive or synergistic, the yields for soybean treated with flumioxazin and VLCFA inhibitor tank mixes were similar to the untreated control. The only treatment for which soybean yield differed from the untreated control (i.e., a $10 \%$ yield increase) was flumioxazin applied at $142 \mathrm{~g} \cdot \mathrm{ai}^{\mathrm{h}} \mathrm{ha}^{-1}$ (Table 2). When early-season herbicide injury is transient, as in this study, detrimental impacts on yield can be overcome in soybean because of a propensity for compensatory growth [33], including when flumioxazin is applied at $448 \mathrm{~g} \cdot \mathrm{ai} \cdot \mathrm{ha}^{-1}$ [25]. Unfortunately, the observed yield increase is likely an anomaly as soybean yields following applications of flumioxazin alone have been shown to be lower than weed-free controls [22] [23].

\section{Conclusion}

Tank mix applications of flumioxazin plus any of the three VLCFA inhibitors tested can cause greater than expected visible injury and greater than expected reductions in height and dry weight of soybean, warranting the warning on the flumioxazin label [8]. Furthermore, interactive effects for other Protox inhibitor and VLCFA inhibitor tank mixes were also observed: additive effects for sulfentrazone on soybean injury and additive or synergistic effects for saflufenacil on all parameters tested. Yet, in this study, the demonstrated impacts were transient as yields for soybean treated with any of the Protox inhibitor and VLCFA inhibitor tank mixes were similar to the untreated control. Caution would be advised before advocating the use of these herbicide treatments at the rates examined. The methodology used in this research removed any confounding effects of soybean-weed competition, a limitation of previous studies [22] [23]. While the incorporation of multiple herbicides to increase the diversity of modes of action used in soybean production systems is a valuable practice to mitigate resistant weed evolution, herbicide stewardship must integrate knowledge of interactive effects of herbicides.

\section{Acknowledgements}

The authors acknowledge Lynette Brown, Todd Cowan, and Peter Smith for their expertise and technical assistance in these studies.

\section{References}

[1] Beckie, H.J. (2011) Herbicide-Resistant Weed Management: Focus on Glyphosate. Pest Management Science, 67, 1037-1048. http://dx.doi.org/10.1002/ps.2195

[2] Johnson, W.G., Davis, V.M., Kruger, G.R. and Weller, S.C. (2009) Influence of Glyphosate-Resistant Cropping Systems on Weed Species Shifts and Glyphosate-Resistant Weed Populations. European Journal of Agronomy, 31, 162172. http://dx.doi.org/10.1016/j.eja.2009.03.008

[3] Young, B.G. (2006) Changes in Herbicide Use Patterns and Production Practices Resulting from Glyphosate-Resistant Crops. Weed Technology, 20, 301-307. http://dx.doi.org/10.1614/WT-04-189.1

[4] Putnam, A.R. and Penner, D. (1974) Pesticide Interactions in Higher Plants. In: Gunther, F.A., Ed., Residue Reviews, 
Springer-Verlag, New York, 73-110. http://dx.doi.org/10.1007/978-1-4615-8501-5_3

[5] Colby, S.R. (1967) Calculating Synergistic and Antagonistic Responses of Herbicide Combinations. Weeds, 15, 20-22. http://dx.doi.org/10.2307/4041058

[6] Duke, S.O., Lydon, J., Becerril, J.M., Sherman, T.D., Lehnen Jr., L.P. and Matsumoto, H. (1991) Protoporphyrinogen Oxidase-Inhibiting Herbicides. Weed Science, 39, 465-473.

[7] Senseman, S.A. (2007) Herbicide Handbook. 9th Edition, Weed Science Society of America, Lawrence.

[8] Anonymous (2010) Valor ${ }^{\circledR}$ SX Herbicide Product Label. Form 2010-VLR-0001. Valent, Walnut Creek, 27 p.

[9] Anonymous (2011) $\operatorname{Spartan}^{\circledR}$ 4F Herbicide Product Label. Spartan 4F 04-01-11 Commercial. FMC. Philadelphia, 14 p.

[10] Anonymous (2012) Sharpen ${ }^{\circledR}$ Herbicide Product Label. NVA 2012-04-322-0046. BASF, Research Triangle Park, 20 p.

[11] Anonymous (2012) Authority Elite ${ }^{\circledR}$ Herbicide Product Label. 06-26-13 Comm. FMC, Philadelphia, 6 p.

[12] Anonymous (2012) Verdict ${ }^{\circledR}$ Herbicide Product Label. NVA 2012-04-320-0174. BASF, Research Triangle Park, 29 p.

[13] Böger, P. (2003) Mode of Action of Chloroacetamides and Functionally Related Compounds. Journal of Pesticide Science, 28, 324-329. http://dx.doi.org/10.1584/jpestics.28.324

[14] Tanetani, Y., Kaku, K., Kawai, K., Fujioka, T. and Shimizu, T. (2009) Action Mechanism of a Novel Herbicide, Pyroxasulfone. Pesticide Biochemistry and Physiology, 95, 47-55. http://dx.doi.org/10.1016/j.pestbp.2009.06.003

[15] Anonymous (2013) Fierce ${ }^{\circledR}$ Herbicide Product Label. Form 2013-FIE-0013. Valent, Walnut Creek, 8 p.

[16] Mahoney, K.J., Shropshire, C. and Sikkema, P.H. (2013) Weed Management in Conventional- and No-Till Soybean (Glycine max) Using Flumioxazin/Pyroxasulfone. Weed Technology, in Press.

[17] Refsell, D.E., Ott, E.J., Dale, T.M. and Pawlak, J.A. (2009) V-10233 Performance in Midwest Soybean Fields. Proceedings of the North Central Weed Science Society, Kansas City, 7-10 December 2009, Abstract 82, North Central Weed Science Society, Champaign.

[18] Stachler, J.M. and Luecke, J.L. (2011) The Utility of Preemergence Herbicides in Glufosinate-Resistant Soybean in a Sugarbeet Rotation in Minnesota and North Dakota. Proceedings of the North Central Weed Science Society, Milwaukee,12-15 December 2011, Abstract 151, North Central Weed Science Society, Milwaukee.

[19] Stachler, J.M., Luecke, J.L. and Fisher, J.M. (2010) Controlling Glyphosate-Resistant Ragweed and Waterhemp with Preemergence Soybean Herbicides Having Safety to Sugarbeet in Rotation. Proceedings of the North Central Weed Science Society, Lexington, 13-16 December 2010, Abstract 172, North Central Weed Science Society, Lexington.

[20] Young, B.G., et al. (2010) Length of Residual Weed Control with V-10266 and Other Preemergence Soybean Herbicides. Proceedings of the North Central Weed Science Society, Lexington, 13-16 December 2010, Abstract 153, North Central Weed Science Society, Lexington.

[21] Miller, R.T., Soltani, N., Robinson, D.E., Kraus, T.E. and Sikkema, P.H. (2012) Soybean (Glycine max) Cultivar Tolerance to Saflufenacil. Canadian Journal of Plant Science, 92, 1319-1328. http://dx.doi.org/10.4141/cjps2012-055

[22] Niekamp, J.W. and Johnson, W.G. (2001) Weed Management with Sulfentrazone and Flumioxazin in No-Tillage Soybean (Glycine max). Crop Protection, 20, 215-220. http://dx.doi.org/10.4141/cjps2012-055

[23] Niekamp, J.W., Johnson, W.G. and Smeda, R.J. (1999) Broadleaf Weed Control with Sulfentrazone and Flumioxazin in No-Tillage Soybean. Weed Technology, 13, 233-238.

[24] Soltani, N., Shropshire, C. and Sikkema, P.H. (2010) Sensitivity of Leguminous Crops to Saflufenacil. Weed Technology, 24, 143-146. http://dx.doi.org/10.1614/WT-09-029.1

[25] Taylor-Lovell, S., Wax, L.M. and Nelson, R. (2001) Phytotoxic Response and Yield of Soybean (Glycine max) Varieties Treated with Sulfentrazone or Flumioxazin. Weed Technology, 15, 95-102. http://dx.doi.org/10.1614/0890-037X(2001)015[0095:PRAYOS]2.0.CO;2

[26] Miller, R.T., Soltani, N., Robinson, D.E., Kraus, T.E. and Sikkema, P.H. (2012) Biologically Effective Rate of Saflufenacil/Dimethenamid-p in Soybean (Glycine max). Canadian Journal of Plant Science, 92, 517-531. http://dx.doi.org/10.4141/cjps2011-253

[27] Norsworthy, J.K. (2004) Soil-Applied Herbicide Use in Wide- and Narrow-Row Glyphosate-Resistant Soybean (Glycine max). Crop Protection, 23, 1237-1244. http://dx.doi.org/10.1016/j.cropro.2004.05.008

[28] Whitaker, J.R., York, A.C., Jordan, D.L. and Culpepper, A.S. (2010) Palmer Amaranth (Amaranthus palmeri) Control in Soybean with Glyphosate and Conventional Herbicide Systems. Weed Technology, 24, 403-410. http://dx.doi.org/10.1614/WT-D-09-00043.1

[29] Hardwick, J.M. (2013) Evaluation of Pyroxasulfone in Corn (Zea mays L.) and Soybean (Glycine max L. Merr.) Weed Management Programs. M.Sc. Dissertation, Louisiana State University, Baton Rouge, 37-62.

[30] Kaastra, A.C., Swanton, C.J., Tardif, F.J. and Sikkema, P.H. (2008) Two-Way Performance Interactions among p-Hy- 
droxyphenylpyruvate Dioxygenase- and Acetolactate Synthase-Inhibiting Herbicides. Weed Science, 56, 841-851. http://dx.doi.org/10.1614/WS-08-061.1

[31] Krausz, R.F. and Young, B.G. (2003) Sulfentrazone Enhances Weed Control of Glyphosate in Glyphosate-Resistant Soybean (Glycine max). Weed Technology, 17, 249-255. http://dx.doi.org/10.1614/0890-037X(2003)017[0249:SEWCOG]2.0.CO;2

[32] Swantek, J.M., Sneller, C.H. and Oliver, L.R. (1998) Evaluation of Soybean Injury from Sulfentrazone and Inheritance of Tolerance. Weed Science, 46, 271-277.

[33] Norsworthy, J.K. (2004) Conventional Soybean Plant and Progeny Response to Glyphosate. Weed Technology, 18, 527-531. http://dx.doi.org/10.1614/WT-03-066R3

\section{Abbreviations}

VLCFA, very long chain fatty acid;

$W A E$, weeks after soybean emergence. 